\title{
Biodiversitas udang pada ekosistem mangrove Teluk Awur, Jepara dan perbandingannya dengan beberapa kawasan ekosistem mangrove di Indonesia
}

\section{Shrimp biodiversity in the mangrove ecosystem of Teluk Awur, Jepara and its comparison with several mangrove ecosystem areas in Indonesia}

\author{
T. M. Faisal ${ }^{1}$, A. Putriningtias ${ }^{1}$, S. Redjeki² ${ }^{2}$ R. Pribadi ${ }^{2}$, R. Pratiwi ${ }^{3}$, H. Akbar ${ }^{1,4^{*}}$ \\ ${ }_{1}^{1}$ Program Studi Akuakultur, Fakultas Pertanian, Universitas Samudra, Langsa, Indonesia \\ 2Departemen Ilmu Kelautan, Fakultas Perikanan dan Ilmu Kelautan, Universitas Diponegoro, Semarang, \\ Indonesia \\ 3Pusat Penelitian Oseanografi-Lembaga Ilmu Pengetahuan Indonesia (LIPI), Jakarta, Indonesia \\ ${ }^{4}$ Pusat Penelitian Lingkungan Hidup, IPB University, Bogor, Indonesia
}

\begin{abstract}
Abstrak.
Kawasan ekosistem mangrove Teluk Awur, Jepara merupakan kawasan mangrove replant (MR). Dibandingkan dengan beberapa lokasi penelitian lain di Indonesia, kawasan Teluk Awur memiliki biodiversitas udang yang tergolong tinggi. Biodiversitas udang yang lebih tinggi ditemukan pada kawasan mangrove replant (MR) yang memiliki usia lebih tua. Biodiversitas udang di Teluk Awur terdiri atas 11 spesies udang (kelas crustacea, sub ordo Natantia) yang berasal dari 4 famili, yaitu: Alpheidae, Penaeidae, Mysidae dan Palaemonidae. Biodiversitas udang didaerah lain terdiri atas $4-12$ spesies dari 2-4 famili. Dapat disimpulkan bahwa pemulihan ekosistem melalui mangrove replant dapat mengembalikan fungsi ekosistem mangrove serta menyediakan relung hidup bagi organisme.
\end{abstract}

Kata kunci: mangrove replant, udang, biodiversitas, ekosistem, Teluk Awur

\begin{abstract}
.
The mangrove ecosystem area of Teluk Awur, Jepara is a mangrove replant (MR) area. Compared to several other research sites in Indonesia, the Teluk Awur area has a relatively high shrimp biodiversity. Higher shrimp biodiversity was found in the mangrove replant (MR) area which had an older age. Shrimp biodiversity in Teluk Awur consists of 11 species of shrimp (crustacean, sub order Natantia) from 4 families: Alpheidae, Penaeidae, Mysidae and Palaemonidae. Shrimp biodiversity in other areas consists of 4-12 species from 2-4 families. It can be concluded that ecosystem restoration through mangrove replanting can restore the function of the mangrove ecosystem and provide living niches for organisms.
\end{abstract}

Keywords: mangrove replant, shrimp, biodiversity, ecosystem, Teluk Awur

\section{PENDAHULUAN}

Tanaman dan hewan berikut interaksinya di ekosistem mangrove memiliki peran penting terhadap populasi, komunitas dan dinamika pada ekosistem (Tomlinson 1994). Krustasea adalah makro bentos yang memainkan peran penting di ekosistem hutan bakau (Hogarth 2007). Krustasea tersebut ditemukan cukup berlimpah di ekosistem mangrove. Udang menjadi salah satu krustasea yang banyak ditemukan di ekosistem mangrove. Larva dan juvenil udang sering berlimpah ditangkap di sekitar pembesaran, yakni di sekitar perairan ekosistem mangrove (Staples et al. 1985). Jumlah udang yang ditangkap setiap tahun berkorelasi positif dengan luasan mangrove di seluruh Indonesia (Martosubroto and Naamin 1977). Penelitian Faisal (2009) bertujuan

\footnotetext{
* Korespondensi Penulis

Email : helmy.akbar85@gmail.com
} 
mengetahui biodiversitas udang (kelas crustacea, sub ordo Natantia) di ekosistem mangrove Teluk Awur, Jepara yang memiliki tahun penanaman vegetasi mangrove yang berbeda. Manfaat penelitian Faisal (2009) secara keilmuan untuk mengetahui pengaruh perbedaan umur vegetasi mangrove terhadap kondisi di ekosistem yang ada di dalamnya, terutama populasi udang.

\section{METODOLOGI}

\subsection{Lokasi kajian dan waktu penelitian}

Lokasi penelitian oleh Faisal (2009) terdiri dari 3 lokasi berdasarkan perbedaan umur vegetasi mangrove. Lokasi pertama (MR I) merupakan vegetasi mangrove berumur 4 tahun dengan jenis vegetasi Rhizophora mucronata memiliki tinggi tanaman sekitar 3,5-4,0 $\mathrm{m}$ dan kerapatan vegetasi 48 ind $/ 100 \mathrm{~m}^{2}$ (Harjo 2009). Lokasi kedua (MR II) merupakan vegetasi mangrove berumur 2 tahun dengan jenis vegetasi Ceriops decandra memiliki tinggi tanaman sekitar 2,5-3,0 $\mathrm{m}$ dan kerapatan vegetasi (52 ind/100 $\mathrm{m}^{2}$ ). Lokasi ketiga (MR III) merupakan vegetasi mangrove berumur 1 tahun dengan jenis vegetasi Rhizophora mucronata memiliki tinggi tanaman sekitar 0,5-1,0 m dan kerapatan vegetasi 44 ind $/ 100 \mathrm{~m}^{2}$ (Gambar 1).

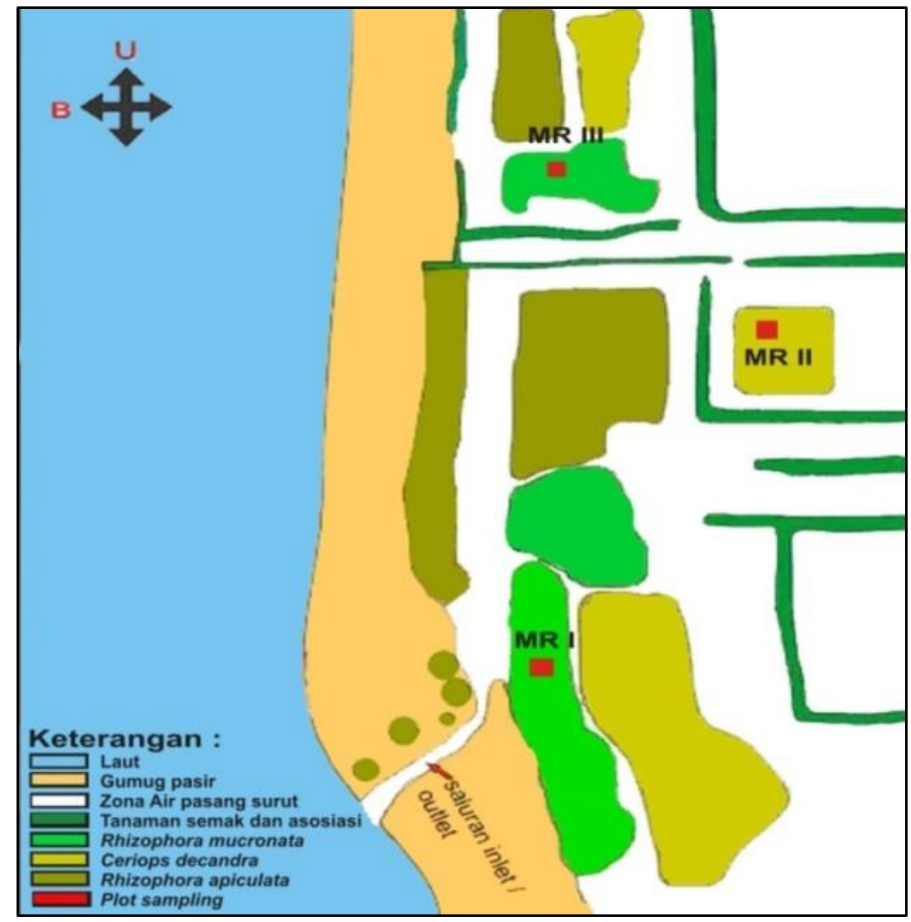

Gambar 1. Denah pemasangan jaring anco (lift net) untuk pengambilan sampel udang di ekosistem mangrove Teluk Awur, Jepara. 
Kualitas air yang diamati meliputi temperatur, kecerahan, salinitas, dan $\mathrm{pH}$. Pengumpulan sampel udang menerapkan metode jaring anco (lift net) berukuran 2,5x2,0 m dan mata jaring $500 \mu \mathrm{m}$. Di setiap lokasi penelitian dilaksanakan pengumpulan sampel udang sebanyak 3 kali ulangan setiap minggu selama 1 bulan (4x). Pengumpulan sampel dilakukan pada pagi hari ketika air laut surut. Preparasi sampel udang mengikuti petunjuk Pratiwi (2008).

\subsection{Prosedur analisis data}

Analisis data biodiversitas udang dilakukan dengan menentukan tingkat kelimpahan, indeks keanekaragaman, indeks keseragaman, indeks dominasi, dan indeks kesamaan komunitas. Kelimpahan merupakan gambaran jumlah individu biota di suatu perairan, dinyatakan sebagai jumlah individu per satuan area (Odum 1993). Perhitungan kelimpahan mengikuti Odum (1993). Dalam penelitian Faisal (2009), kelimpahan menggambarkan jumlah individu per $5 \mathrm{~m}^{2}$ diperoleh dari 2,5×2,0 m luas jaring anco (lift net). Indeks keanekaragaman menggambarkan tingkat keanekaragaman jenis dari organisme yang terdapat dalam komunitas (Odum 1971). Dalam penelitian ini, rumus yang digunakan mengikuti perhitungan Shannon-Wienner (Odum 1971). Kriteria Indeks Keanekaragaman dibagi menjadi 3, mengikuti Wilhm (1975). Perhitungan indeks keseragaman (e) mengikuti Odum (1971) dengan kisaran indeks mengikuti Krebs (1985). Indeks dominasi menggunakan rumus Simpsons (1949) dalam Odum (1971). Adapun, indeks kesamaan komunitas adalah indeks yang membandingkan tingkat kesamaan antara dua komunitas dengan perhitungan mengikuti Odum (1993).

\section{HASIL DAN PEMBAHASAN}

Kegiatan mangrove replant ini telah dilakukan setiap tahun mulai tahun 2001, namun hanya di lokasi penanaman tahun 2004, 2006 dan 2007 saja yang dijadikan sebagai lokasi penelitian Faisal (2009), karena dinilai mempunyai kenampakan vegetasi yang cukup berbeda/signifikan. Penelitian Faisal (2009) dilakukan pada vegetasi Ceriops decandra dan Rhizophora mucronata, karena hanya dua jenis itu yang terdapat pada ketiga areal penanaman tersebut.

\subsection{Kondisi lingkungan perairan}

Nilai temperatur, kecerahan, salinitas dan $\mathrm{pH}$ pada setiap lokasi pengambilan contoh tidak berbeda secara berarti. Rataan $\mathrm{pH}$ adalah 7 , antar waktu pengambilan pagi (I) dan sore (II) tak memperlihatkan perbedaan. Temperatur berkisar $26-31^{\circ} \mathrm{C}$, sedangkan kecerahan berkisar $11-29 \mathrm{~cm}$ dengan pengukuran mencapai $100 \%$ (sampai pada dasar perairan). Salinitas tidak jauh berbeda yakni berkisar 33,6-34,8 psu. 


\subsection{Identifikasi dan komposisi udang (kelas crustacea, sub ordo Natantia)}

Faisal (2009) menemukan sedikitnya 11 spesies udang (kelas crustacea, sub ordo Natantia) yang berasal dari 4 famili yaitu Alpheus microrhynchus de Man, 1897 (Alpheidae); Metapenaeus ensis de Haan, 1844, Metapenaeus sp. Wood-Mason, 1819, Penaeus merguiensis de Man, 1888 dan Penaeus semisulcatus de Haan, 1844 (Penaeidae); Mysis sp. (Mysidae); Palaemon longirostris H.MilneEdward, 1837, Palaemon sp. Weber, 1795, Palaemonela sp. Dana, 1852, Palaemonella vestigialis Kemp, 1922 dan Palaemonetes sp. Heller, 1869 (Palaemonidae). Adapun gambar sketsa dan foto udang yang ditemukan di lokasi penelitian tersaji dalam Gambar 2. Sebanyak 11 spesies udang tersebut ditemukan pada semua lokasi penelitian, meskipun tidak selalu ditemukan pada tiap pengulangan pengangkatan jaring sampel dan kelimpahan yang bervariasi. Dimana MR I dengan vegetasi yang lebih tua memiliki jumlah individu lebih tinggi dibanding MR II dan MR III yang jauh lebih muda (Gambar 3), Berdasarkan jumlah individunya juga diketahui bahwa spesies udang yang paling dominan di semua lokasi penelitian adalah Penaeus merguiensis, sedangkan yang paling sedikit dijumpai adalah Alpheus microrhynchus.

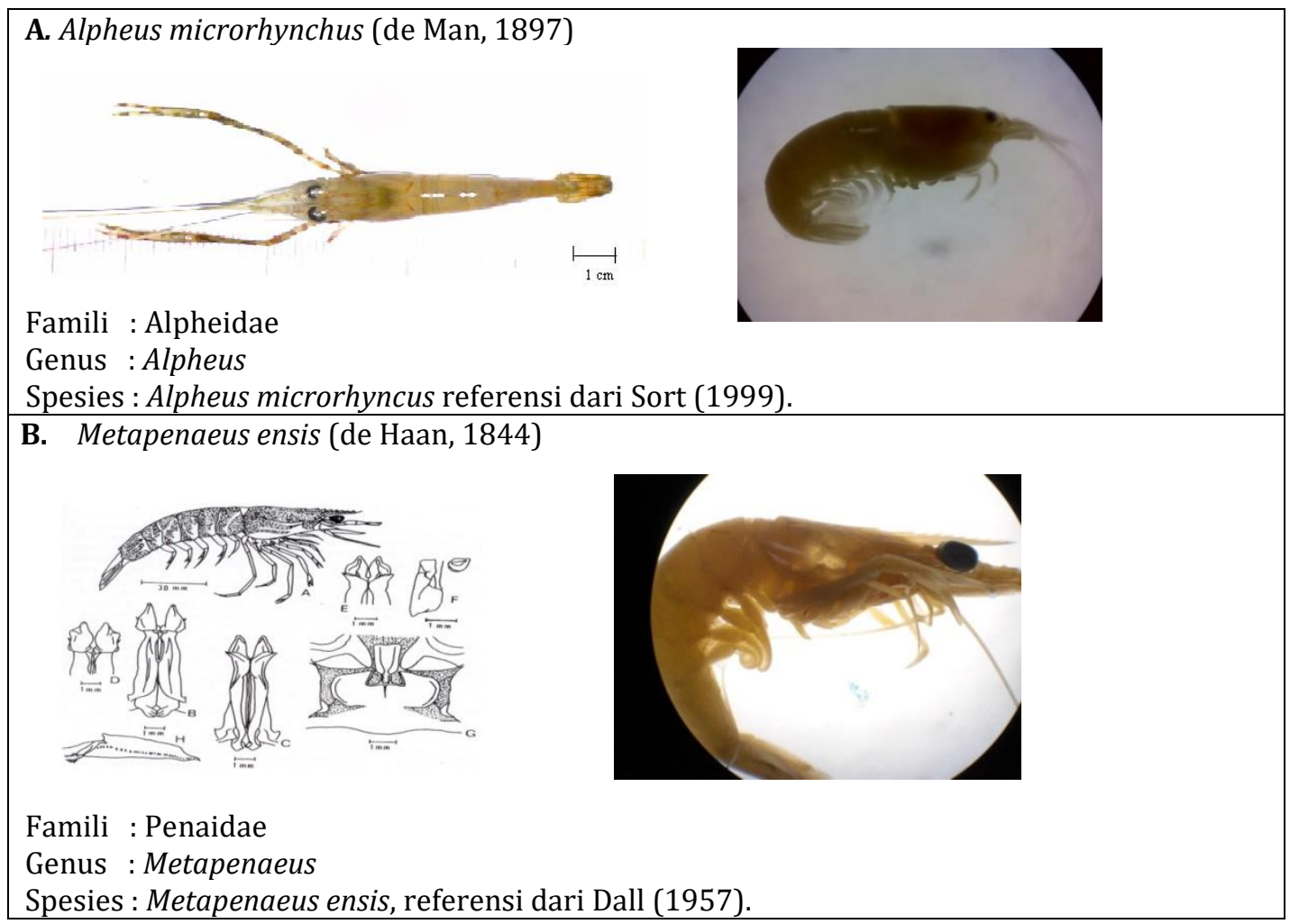


C. Metapenaeus sp. (Wood-Mason, 1819)
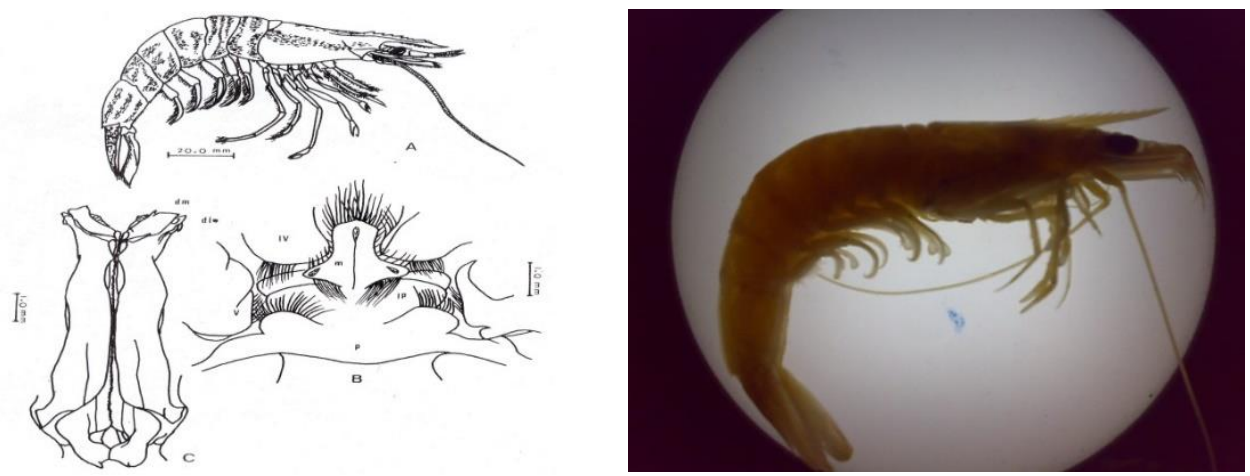

Famili : Penaidae

Genus : Metapenaeus

Spesies : Metapenaeus sp.

D. Palaemon longirostris (H.Milne-Edward, 1837)
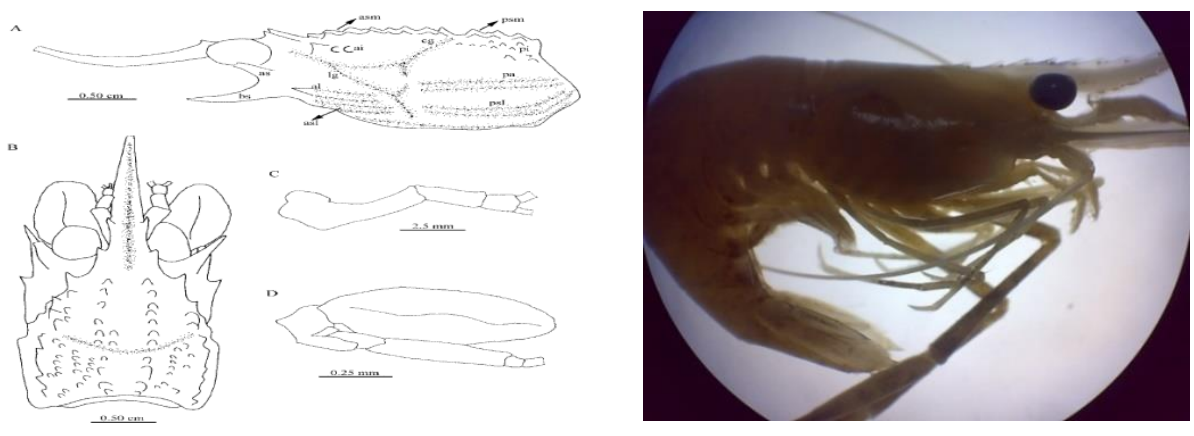

Famili : Palaemonidae

Genus : Palaemon

Spesies : Palaemon longirostris

E. Palaemon sp. (Weber, 1795)
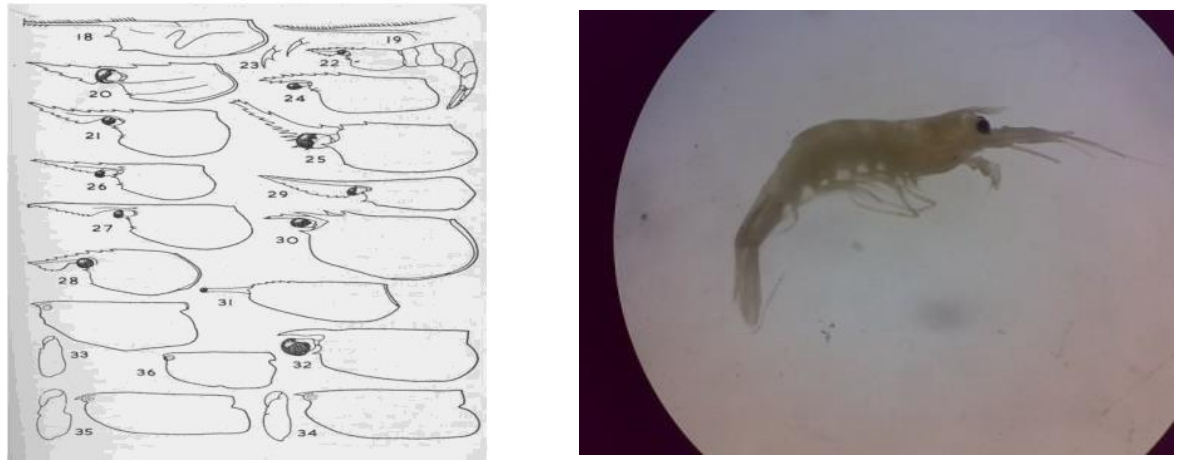

Famili : Palaemonidae

Genus : Palaemon

Spesies : Palaemon sp. 

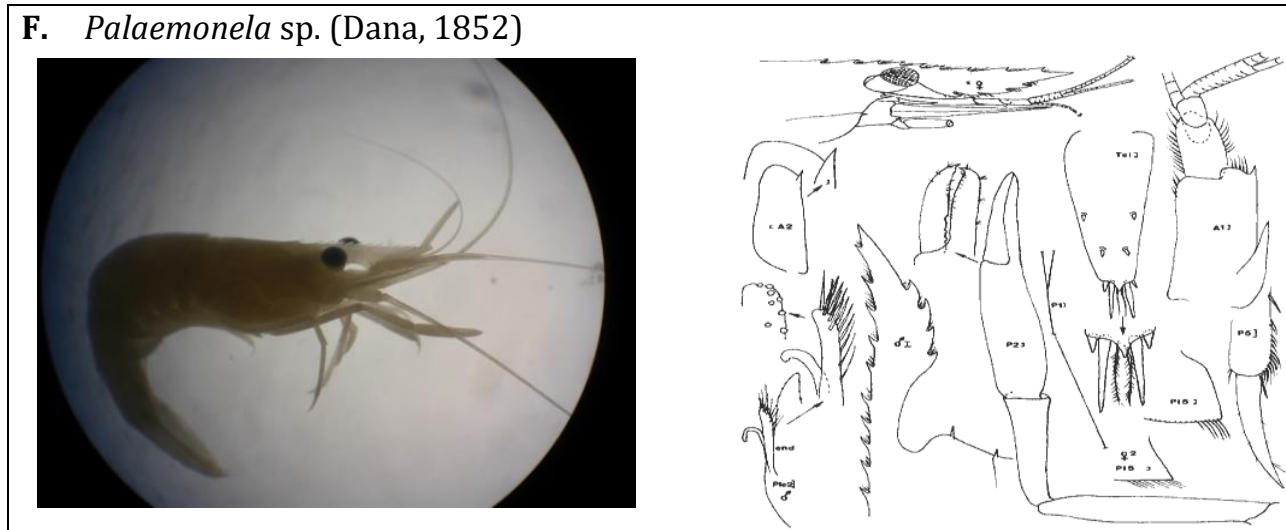

Famili : Palaemonidae

Genus : Palaemonella

Spesies : Palaemonella sp.

G. Palaemonella vestigialis (Kemp, 1922)
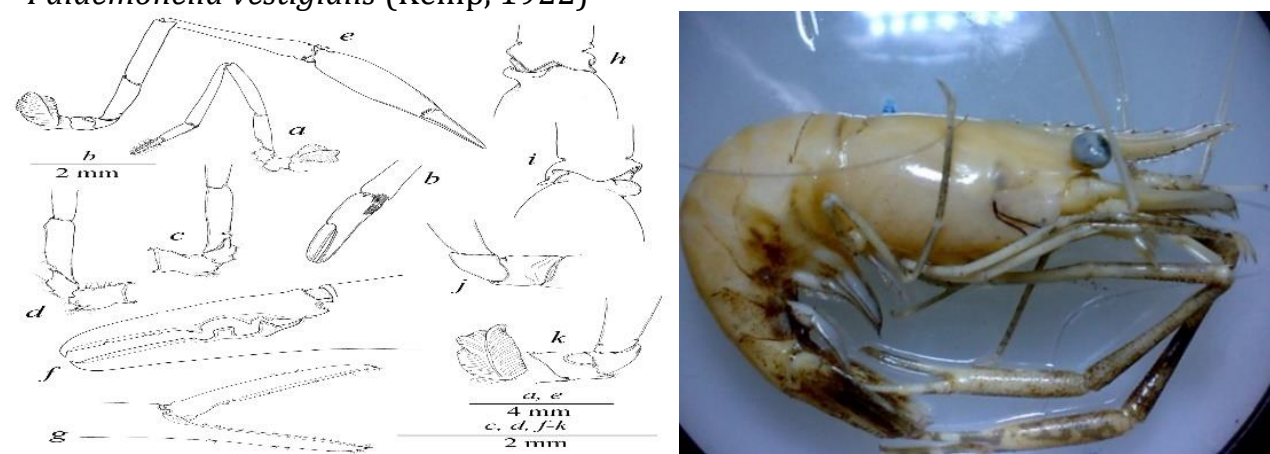

Famili : Palaemonidae

Genus : Palaemonella

Spesies : Palaemonella vestigialis

H. Penaeus semisulcatus (de Haan, 1844)
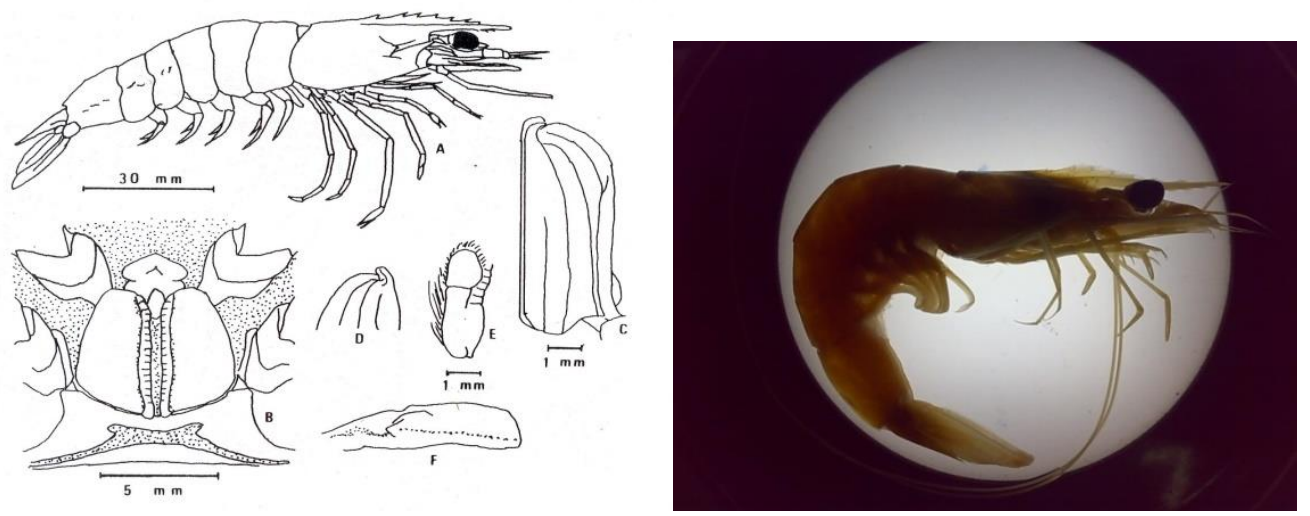

Famili : Penaidae

Genus : Penaeus

Spesies : Penaeus semisulcatus, referensi dari Dall (1957). 
I. Penaeus merguiensis (de Man, 1888)
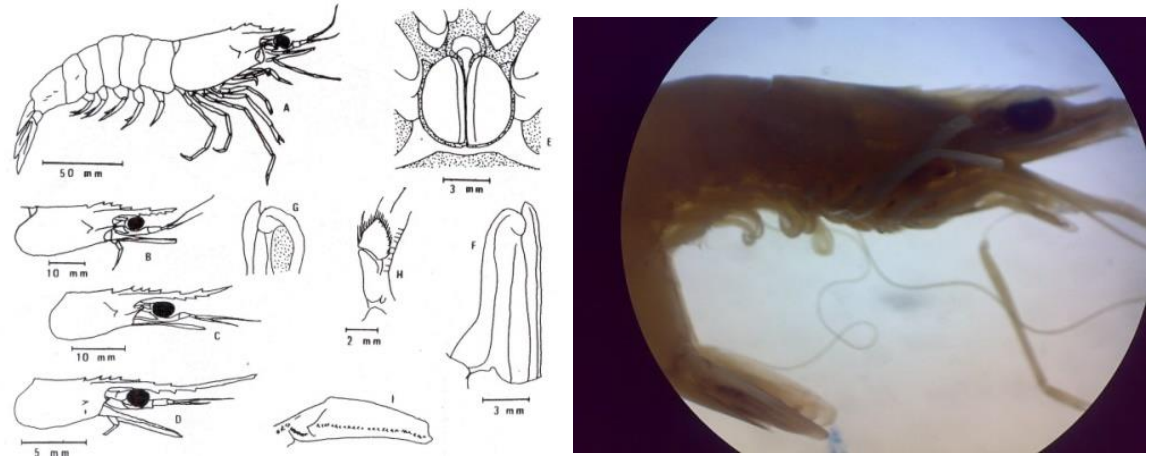

Famili : Penaidae

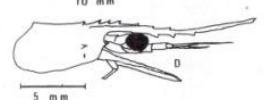

Genus : Penaeus

Spesies : Penaeus merguiensis, referensi dari Dall (1957).

J. Mysis sp.
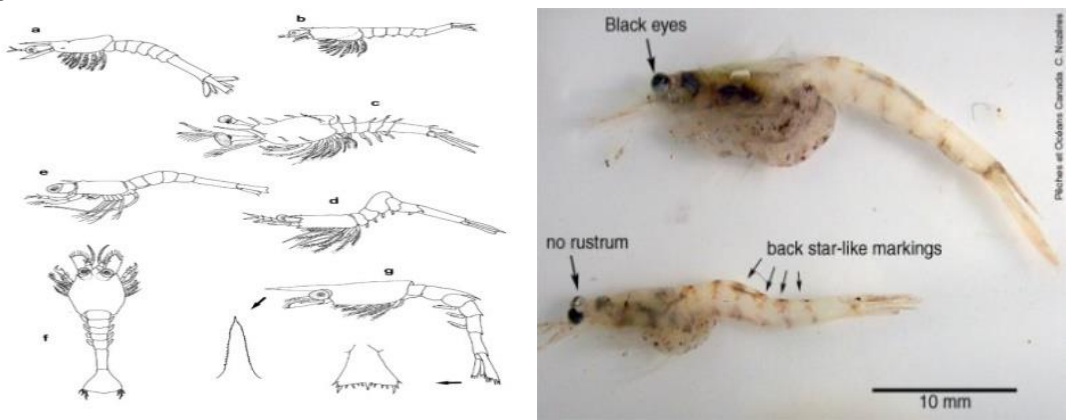

Famili : Mysidae

Genus : Mysis

Spesies : Mysis sp.

\section{K. Palaemonetes sp. (Heller, 1869)}

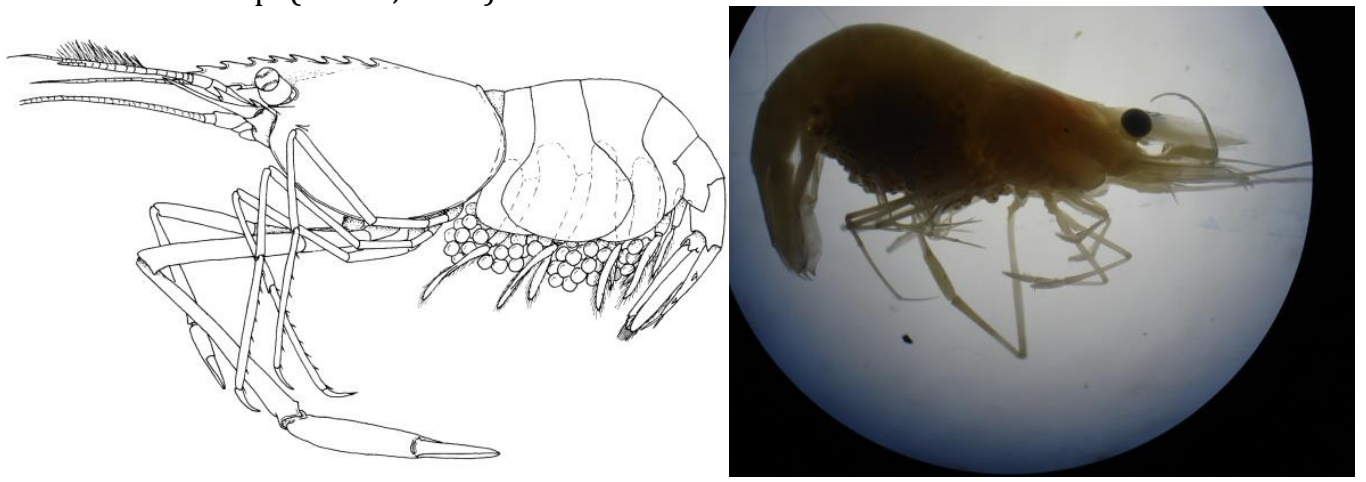

Famili : Palaemonidae

Genus : Palaemonetes

Spesies : Palaemonetes sp.

Gambar 2. Spesies udang (kelas crustacea, sub ordo Natantia) yang ditemukan pada lokasi penelitian di ekosistem mangrove Teluk Awur, Jepara. 


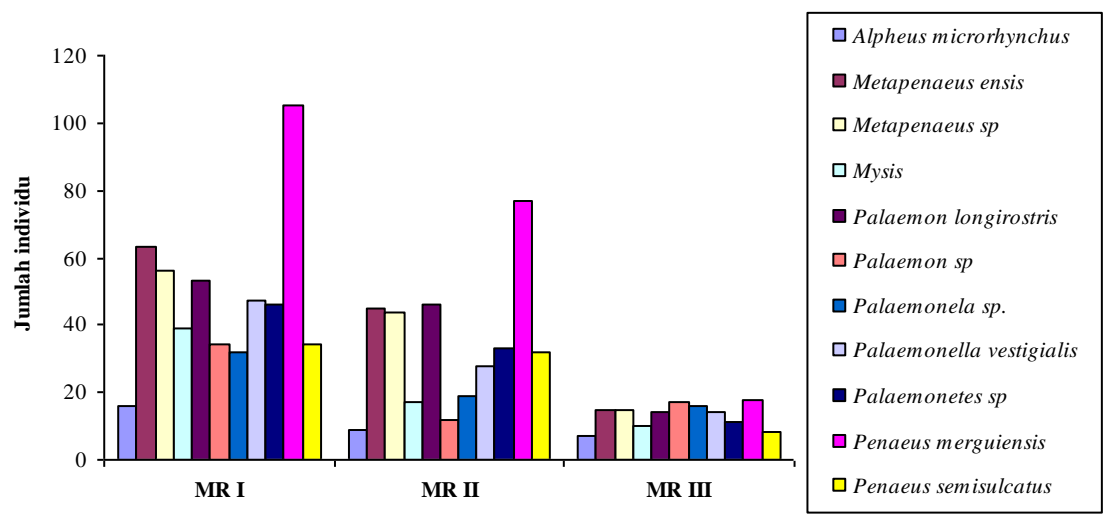

Gambar 3. Distribusi jumlah individu dari masing-masing spesies udang pada lokasi penelitian di ekosistem mangrove Teluk Awur, Jepara.

\subsection{Kelimpahan udang}

Secara umum kelimpahan tertinggi terdapat pada lokasi MR I sebesar 6 ind $/ 5 \mathrm{~m}^{2}$ dan terendah di MR III ( 2 ind $\left./ 5 \mathrm{~m}^{2}\right)$, sebagaimana data jumlah individu MR I yang memiliki vegetasi yang lebih tua juga cenderung lebih tinggi kelimpahannya daripada MR II dan MR III. Berdasarkan waktu pengamatan, kelimpahan udang tidak jauh berbeda antar minggu pengamatan di setiap lokasi penelitian (Tabel 1). Kelimpahan yang tertinggi ditemukan pada minggu ketiga namun demikian sebaliknya pada MR III justru lebih rendah pada minggu ketiga.

Tabel 1. Nilai rata-rata kelimpahan udang (ind $\left./ 5 \mathrm{~m}^{2}\right)$ dan kisarannya $(\mathrm{n}=3)$ pada masingmasing lokasi penelitian dan minggu pengamatan di ekosistem mangrove Teluk Awur, Jepara.

\begin{tabular}{ccccccc}
\hline \multirow{2}{*}{ Lokasi } & \multicolumn{5}{c}{ Minggu } & \multirow{2}{*}{ Rata-rata } \\
\cline { 2 - 5 } & I & II & III & IV & \\
\hline \multirow{2}{*}{ MR I } & 4 & 5 & 7 & 6 & 6 \\
& $(3-5)$ & $(4-7)$ & $(3-9)$ & $(4-8)$ & \multirow{2}{*}{ MR II } \\
& 4 & 4 & 5 & 4 & 4 \\
\multirow{2}{*}{ MR III } & $(2-6)$ & $(1-7)$ & $(2-8)$ & $(0-7)$ & 2 \\
& 2 & 3 & 2 & 2 & \multirow{2}{*}{$(1-4)$} \\
\hline
\end{tabular}

\subsection{Indeks keanekaragaman, keseragaman dan dominasi}

Indeks Keanekaragaman $\left(\mathrm{H}^{\prime}\right)$, Keseragaman (e) dan Dominasi (C) udang pada tiap lokasi penelitian Faisal (2009) tertera pada Tabel 2. Indeks keanekaragaman di semua lokasi penelitian termasuk dalam kategori tinggi dengan nilai berkisar dari 3,06-5,32 (Wilhm 1975). Berdasarkan lokasinya, pada mangrove replant (MR) indeks keanekaragaman terkategori tinggi dengan nilai MR masing-masing sebesar 4,91-5,32 (MR I), 4,61-4,94 (MR II) dan 3,06-3,78 (MR III) (Tabel 2). Indeks tertinggi di MR I $(5,32)$ dan terendah di MR III $(3,06)$. 
Indeks keseragaman di semua lokasi penelitian berkategori tinggi (Krebs 1985) dengan nilai berkisar antara 0,62-0,74. Berdasarkan lokasinya, indeks keseragaman di masing-masing MR termasuk kategori tinggi, pada MR I dan MR II ditemukan nilai yang sama yaitu berkisar antara 0,71-0,74 sedangkan MR III dengan nilai berkisar antara 0,62-0,70. Nilai indeks tertinggi terdapat pada MR I dan MR II $(0,74)$ dan terendah terdapat pada MR III $(0,62)$.

Tabel 2. Indeks keanekaragaman, keseragaman dan dominasi udang pada masing-masing lokasi penelitian dan minggu pengamatan di ekosistem mangrove Teluk Awur, Jepara.

\begin{tabular}{cccccccc}
\hline Lokasi & Minggu & $\mathrm{H}^{\prime}$ & Kategori & $\mathrm{e}$ & Kategori & $\mathrm{C}$ & Kategori $^{*}$ \\
\hline \multirow{4}{*}{ MR I } & 1 & 4,98 & Tinggi & 0,71 & Tinggi & 1,70 & $\mathrm{AD}$ \\
& 2 & 4,91 & Tinggi & 0,72 & Tinggi & 1,40 & $\mathrm{AD}$ \\
& 3 & 5,16 & Tinggi & 0,73 & Tinggi & 1,80 & $\mathrm{AD}$ \\
& 4 & 5,32 & Tinggi & 0,74 & Tinggi & 2,00 & $\mathrm{AD}$ \\
\hline \multirow{4}{*}{ MR II } & Rata-rata & 5,09 & Tinggi & 0,73 & Tinggi & 1,73 & $\mathrm{AD}$ \\
& 1 & 4,65 & Tinggi & 0,73 & Tinggi & 0,80 & $\mathrm{AD}$ \\
& 2 & 4,65 & Tinggi & 0,71 & Tinggi & 1,00 & $\mathrm{AD}$ \\
& 3 & 4,94 & Tinggi & 0,73 & Tinggi & 1,20 & $\mathrm{AD}$ \\
& 4 & 4,61 & Tinggi & 0,74 & Tinggi & 0,70 & $\mathrm{AD}$ \\
\hline \multirow{4}{*}{ MR III } & Rata-rata & 4,71 & Tinggi & 0,73 & Tinggi & 0,90 & $\mathrm{AD}$ \\
& 1 & 3,23 & Tinggi & 0,63 & Tinggi & 0,10 & TAD \\
& 2 & 3,78 & Tinggi & 0,70 & Tinggi & 0,20 & TAD \\
& 3 & 3,06 & Tinggi & 0,62 & Tinggi & 0,10 & TAD \\
\cline { 2 - 7 } & 4 & 3,34 & Tinggi & 0,64 & Tinggi & 0,20 & TAD \\
\hline
\end{tabular}

Keterangan:

*AD (ada dominasi), TAD (tidak ada dominasi).

Secara umum menurut Simpson (1949), MR I dan MR II termasuk kategori ada spesies yang mendominasi dengan nilai indeks dominasi rata-rata MR I $(1,73)$ dan MR II $(0,90)$ sementara MR III berkategori tidak ada spesies yang mendominasi dengan nilai rata-rata $(0,14)$ (Tabel 2). Walaupun lokasi MR I dan MR II sama-sama berkategori adanya spesies yang mendominasi namun pada MR I $(1,73)$ memiliki nilai rata-rata lebih tinggi dibanding MR II $(0,90)$ (Tabel 2).

\subsection{Indeks kesamaan komunitas}

Berdasarkan lokasinya, indeks kesamaan komunitas yang terdapat di lokasi penelitian memiliki nilai optimal $100 \%$ yang menunjukkan bahwa semua spesies udang di temukan di semua lokasi penelitian. Menurut Odum (1993), indeks kesamaan komunitas di semua lokasi penelitian termasuk dalam kategori sangat tinggi, walaupun dari struktur dan jumlah individu yang ditemukan di lokasi penelitian berbeda. Beberapa studi mengenai biodiversitas udang telah dilakukan di perairan Jawa Tengah oleh Zurochman (2003) dan Faisal (2009) diperoleh sedikitnya 11 spesies udang (kelas crustacea, sub ordo Natantia) yang 
berasal dari 4 famili, Putriningtias et al. (2017) (3 famili, 4 spesies), Rahayu et al. (2017) (3 famili, 6 spesies). Studi di perairan pesisir Kulon Progo, Yogyakarta juga pernah dilakukan oleh Amalia et al. (2017) (2 famili, 4 spesies), di Perairan Tanjung Pinang oleh Asian et al. (2015) (4 famili, 6 spesies) dan Kepulauan Anambas, Kepulauan Riau oleh Puspita dan Angella (2014) (4 famili, 10 spesies) juga telah berhasil melakukan pendataan terhadap sejumlah spesies. Penelitian di perairan Kuala Langsa, Aceh oleh Faisal et al. (2019) diperoleh 2 famili (5 spesies), serta oleh Damora et al. (2019) diperoleh 1 famili (3 spesies). Penelitian oleh Pratiwi dan Astuti (2012) di perairan Kendari, Sulawesi Tenggara diperoleh lebih banyak spesies udang yaitu 12 spesies terdiri dari 4 kelompok famili. Selanjutnya, penelitian dari Maulidar dan Samosir (2016) di Kabupaten Indramayu, Jawa Barat diperoleh 8 spesies yang terbagi ke dalam 4 kelompok famili. Secara detail perbandingan hasil penelitian dapat dilihat pada Tabel 3.

Tabel 3. Penelitian biodiversitas udang di beberapa lokasi perairan pesisir di Indonesia.

\begin{tabular}{|c|c|c|c|c|}
\hline Famili & Spesies & Lokasi & $\begin{array}{c}\text { Tahun } \\
\text { pengambilan } \\
\text { data }\end{array}$ & Pustaka \\
\hline $\begin{array}{l}\text { Alpheidae } \\
\text { Penaeidae }\end{array}$ & $\begin{array}{l}\text { Alpheus microrhynchus } \\
\text { Metapenaeus ensis } \\
\text { Metapenaeus sp. } \\
\text { Penaeus merguiensis } \\
\text { Penaeus semisulcatus } \\
\text { Mysis sp. } \\
\text { Palaemon longirostris, } \\
\text { Palaemon sp. } \\
\text { Palaemonela sp. } \\
\text { Palaemonella vestigialis } \\
\text { Palaemonetes sp. }\end{array}$ & $\begin{array}{l}\text { Teluk Awur Jepara, } \\
\text { Provinsi Jawa Tengah }\end{array}$ & 2008 & Faisal (2009) \\
\hline $\begin{array}{l}\text { Alpheidae } \\
\text { Palaemonidae } \\
\text { Mysidae } \\
\end{array}$ & $\begin{array}{l}\text { Alpheus sp. } \\
\text { Alpheus microrhynchus } \\
\text { Palaemon sp. } \\
\text { Mysis sp. }\end{array}$ & $\begin{array}{c}\text { Kelurahan Tugurejo, } \\
\text { Kecamatan Tugu, } \\
\text { Kota Semarang, } \\
\text { Provinsi Jawa Tengah } \\
\end{array}$ & $2010-2011$ & $\begin{array}{l}\text { Putriningtias } \\
\text { et al. (2017) }\end{array}$ \\
\hline Squillidae & $\begin{array}{l}\text { Oratosquilla nepa } \\
\text { Oratosquilla ornata } \\
\text { Oratosquilla solicitans } \\
\text { Oratosquilla oratoria } \\
\text { Harpiosquila harpax }\end{array}$ & & & \\
\hline $\begin{array}{l}\text { Alpheidae } \\
\text { Galatheidae }\end{array}$ & $\begin{array}{l}\text { Metapenaeus ensis } \\
\text { Metapenaeus indicus } \\
\text { Metapenaeus elegans } \\
\text { Penaeus merguiensis } \\
\text { Penaeus monodon } \\
\text { Penaeus semisulcatus } \\
\text { Trachypenaeus fulvus } \\
\text { (Tidak disebutkan) } \\
\text { (Tidak disebutkan) }\end{array}$ & $\begin{array}{c}\text { Perairan Kendari, } \\
\text { Provinsi Sulawesi } \\
\text { Tenggara }\end{array}$ & 2011 & $\begin{array}{c}\text { Pratiwi dan } \\
\text { Astuti (2012) }\end{array}$ \\
\hline
\end{tabular}




\begin{tabular}{|c|c|c|c|c|}
\hline Famili & Spesies & Lokasi & $\begin{array}{l}\text { Tahun } \\
\text { pengambilan } \\
\text { data }\end{array}$ & Pustaka \\
\hline $\begin{array}{l}\text { Odontodactylidae } \\
\text { Alpheidae } \\
\text { Palamonidae }\end{array}$ & $\begin{array}{l}\text { Penaeus monodon } \\
\text { Penaeus penicillatus } \\
\text { Penaeus semisulcatus } \\
\text { Penaeus latisulcatus } \\
\text { Metapenaeus sp } \\
\text { Odontodactylus sp } \\
\text { Alpheus saxidomus } \\
\text { Macrobrachium sp.(1) } \\
\text { Macrobrachium sp.(2) } \\
\text { Macrobrachium sp.(3) }\end{array}$ & $\begin{array}{c}\text { Perairan Kecamatan } \\
\text { Siantan, Kabupaten } \\
\text { Kepulauan Anambas, } \\
\text { Provinsi Kepulauan } \\
\text { Riau }\end{array}$ & 2012 & $\begin{array}{l}\text { Puspita dan } \\
\text { Angella } \\
\text { (2014) }\end{array}$ \\
\hline $\begin{array}{l}\text { Squillidae } \\
\text { Penaeidae } \\
\text { Palaemonidae } \\
\text { Sergestidae }\end{array}$ & $\begin{array}{l}\text { H. Squilidae, } \\
\text { Metapenaeus ensis. } \\
\text { Penaeus merguiensis, } \\
\text { Penaeus monodon, } \\
\text { Penaeus japonicus, } \\
\text { Macrobrachium } \\
\text { monoceros, } \\
\text { Macrobrachium } \\
\text { rosenbergii, } \\
\text { Acetes sp. } \\
\end{array}$ & $\begin{array}{c}\text { Kecamatan Pasekan, } \\
\text { Kabupaten } \\
\text { Indramayu, Provinsi } \\
\text { Jawa Barat }\end{array}$ & 2013 & $\begin{array}{l}\text { Maulidar dan } \\
\text { Samosir } \\
(2016)\end{array}$ \\
\hline $\begin{array}{l}\text { Aristeidae } \\
\text { Palaemonidae } \\
\text { Penaidae } \\
\text { Nematocarcinidae }\end{array}$ & $\begin{array}{l}\text { Aristaeopsis } \\
\text { edwardsiana } \\
\text { Macrobrachium } \\
\text { rosenbergii } \\
\text { Penaeus merguiensis } \\
\text { Peneus monodon } \\
\text { Penaeus semisulcatus } \\
\text { Nematocarcinus } \\
\text { lanceopes }\end{array}$ & $\begin{array}{l}\text { Kampung Bugis, } \\
\text { Kecamatan Tanjung } \\
\text { Pinang, Provinsi } \\
\text { Kepulauan Riau }\end{array}$ & 2015 & $\begin{array}{l}\text { Asian et al. } \\
\text { (2015) }\end{array}$ \\
\hline $\begin{array}{l}\text { Alpheidae } \\
\text { Palaemonidae }\end{array}$ & $\begin{array}{l}\text { Penaeus monodon } \\
\text { Penaeus merguiensis } \\
\text { Penaeus sp } \\
\text { Alpheus microrhynchus } \\
\text { Alpheus euprosyne } \\
\text { Macrobrachium } \\
\text { equidens }\end{array}$ & $\begin{array}{c}\text { Kawasan Mangrove, } \\
\text { Kabupaten } \\
\text { Purworejo, Provinsi } \\
\text { Jawa Tengah }\end{array}$ & 2016 & $\begin{array}{l}\text { Rahayu et al. } \\
\quad \text { (2017) }\end{array}$ \\
\hline $\begin{array}{l}\text { Penaeidae } \\
\text { Palaemonidae }\end{array}$ & $\begin{array}{l}\text { Litopenaeus vannamei } \\
\text { Penaeus merguiensis } \\
\text { Penaeus monodon } \\
\text { Macrobrachium } \\
\text { rosenbergii }\end{array}$ & $\begin{array}{c}\text { Desa Jangkaran } \\
\text { Kabupaten Kulon } \\
\text { Progo, Provinsi D. I. } \\
\text { Yogyakarta }\end{array}$ & 2016 & $\begin{array}{l}\text { Amalia et al. } \\
\text { (2017) }\end{array}$ \\
\hline Palaemonidae & $\begin{array}{l}\text { Penaeus monodon } \\
\text { Penaeus indicus } \\
\text { Metapenaeus monoceros } \\
\text { Penaeus vannamei } \\
\text { Palaemon sp. }\end{array}$ & $\begin{array}{l}\text { Kuala Langsa, } \\
\text { Provinsi Aceh }\end{array}$ & 2017 & $\begin{array}{l}\text { Faisal et al. } \\
\text { (2019) }\end{array}$ \\
\hline Penaeidae & $\begin{array}{l}\text { Fenneropenaeus indicus } \\
\text { Fenneropenaeus } \\
\text { merguiensis } \\
\text { Penaeus monodon }\end{array}$ & $\begin{array}{l}\text { Kuala Langsa, } \\
\text { Provinsi Aceh }\end{array}$ & 2018 & $\begin{array}{c}\text { Damora et al. } \\
\text { (2019) }\end{array}$ \\
\hline
\end{tabular}


Penelitian Faisal (2009) menunjukkan bahwa pemulihan ekosistem melalui mangrove replant dapat mengembalikan fungsi ekosistem mangrove dan menyediakan relung hidup bagi organisme. Hal ini sesuai dengan pendapat Ruslan (1976) dalam Martosubroto and Naamin (1977) yang menyimpulkan bahwa di pantai timur Provinsi Nanggroe Aceh Darussalam terdapat hubungan yang nyata (signifikan) antara luas kawasan mangrove dengan hasil tangkapan udang oleh nelayan.

\section{KESIMPULAN DAN SARAN}

Hasil penelitian menunjukkan bahwa aktivitas mangrove replant dapat mengembalikan fungsi ekosistem. Dibandingkan dengan beberapa lokasi penelitian lain di Indonesia, kawasan Teluk Awur memiliki biodiversitas udang yang tergolong tinggi. Secara umum berdasarkan lokasinya, indeks kesamaan komunitas udang termasuk dalam kategori sangat tinggi dengan nilai optimal $100 \%$, dikarenakan jumlah spesies yang ditemukan di lokasi penelitian sama walaupun struktur dan jumlah individunya tidak sama. Ke depan perlu adanya penelitian yang mengarah kepada pemetaan sumber daya udang, baik yang bersifat ekonomis maupun non ekonomis sebagai upaya pemantauan ekologis.

\section{UCAPAN TERIMAKASIH}

Penulis mengucapkan terima kasih kepada Dra. Rianta Pratiwi, MSc yang membantu untuk identifikasi sampel udang di Laboratorium Koleksi Basah Biota Laut, Pusat Penelitian Oseanografi (P20), LIPI, Ancol, Jakarta.

\section{DAFTAR PUSTAKA}

Amalia SB, Djumanto D dan Probosunu N. 2017. Komunitas krustasea di kawasan mangrove Desa Jangkaran Kabupaten Kulon Progo. Jurnal Perikanan Universitas Gadjah Mada 19(2):79-88.

Asian R, Razai TS dan Zen LW. 2015. Struktur komunitas decapoda di perairan Kampung Bugis, Kelurahan Kampung Bugis, Kecamatan Tanjungpinang Kota. Universitas Maritim Raja Ali Haji. Tanjung Pinang.

Dall W. 1957. A revision of the Australian species of Penaeinae (Crustacea: Decapoda: Penaeidae). Australian Journal of Marine and Freshwater Research 8:136-232.

Damora A, Iqbal TH, Firmanhadi F, Dewiyanti I, Umam AH and Persada AY. Distribution of three species of Penaeus in mangrove ecosystem area of Langsa, Aceh, Indonesia. IOP Conf. Ser.: Earth Environ. Sci. 348 (012112). https://doi.org/10.1088/1755-1315/348/1/012112. 
Faisal TM. 2009. Struktur komunitas udang (kelas crustacea, sub ordo natantia) di ekosistem mangrove Teluk Awur, Jepara [Skripsi]. Fakultas Perikanan dan Ilmu Kelautan, Universitas Diponegoro. Semarang.

Faisal TM, Akbar H, Putriningtias A and Putra SA. 2019. Short communication: community structure of prawns (Decapoda: Penaeidae and Palaemonidae) in mangrove inlets of Kuala Langsa, Aceh, Indonesia. Biodiversitas. 20(5):1306-1311. https://doi.org/10.13057/biodiv/d200509.

Harjo AM. 2009. Studi pertumbuhan, morfometri dan tingkat herbivori daun mangrove Rhizophora mucronata dan Ceriops decandra hasil reforestasi di Pantai Teluk Awur, Jepara [unpublished].

Hogarth PJ. 2007. The biology of mangroves. Oxford University Press Inc,. New York.

Krebs CJ. 1985. Ecology: the experimental analysis of distribution and abundance. Harper and Row Publisher. New York.

Martosubroto $\mathrm{P}$ and Naamin N. 1977. Relationship between tidal forest (mangrove) and commercial shrimp production in Indonesia. Marine Research in Indonesia 18:81-86.

Maulidar R dan Samosir AM. 2016. Keterkaitan antara produktivitas udang dengan kondisi mangrove di Delta Cimanuk, Indramayu, Jawa Barat. Bonorowo Wetlands 6(1):59-68. https://doi.org/10.13057/bonorowo/ w060105.

Odum EP. 1971. Fundamentals of ecology, third edition. WB Saunders Co. Philadelphia.

Odum EP. 1993. Dasar-dasar ekologi. Gramedia. Jakarta.

Pratiwi R. 2008. Modul sosialisasi pelatihan sumberdaya manusia kelautan Indonesia (PSM-TKI). P20 LIPI. Jakarta.

Pratiwi R dan Astuti 0. 2012. Biodiversitas krustasea (Decapoda, Brachyura, Macrura) dari ekspedisi perairan Kendari 2011. ILMU KELAUTAN: Indonesian Journal of Marine Sciences 17(1):8-14. https://doi.org/ 10.14710/ik.ijms.17.1.8-14

Puspita L dan Angella N. 2014. Struktur komunitas udang (crustacea) di perairan pesisir Kecamatan Siantan Kabupaten Kepulauan Anambas Provinsi Kepulauan Riau. Jurnal Simbiosa 3(1):33-41.

Putriningtias A, Pribadi R dan Hartati R. 2017. Struktur komunitas makrobentos krustasea di vegetasi mangrove Kelurahan Tugurejo, Kecamatan Tugu, Kota Semarang. Jurnal Samudra Akuatika 1(1):55-63.

Rahayu SM, Wiryanto W dan Sunarto J. 2017. Keanekaragaman jenis krustasea di kawasan mangrove Kabupaten Purworejo, Jawa Tengah. Jurnal Sains Dasar 6(1):57-65. 
Simpson EH. 1949. Measurement of diversity. Nature 163:688. https://doi.org/ 10.1038/163688a0.

Sort J. 1999. Key to the estuarine/inshore marine prawns of the Timika Area [unpublished]. Environmental Departement of PT. Freeport Indonesia.

Staples DJ, Vance DJ and Heales DS. 1985. Habitat requirement of juvenile penaeid prawns and their relationship to offshore fisheries. In: Rothlisberry PC, Hill BJ and Staples DJ. 1984. 2nd Australian National Prawn Seminar. National Prawn Seminar 2. Cleveland.

Tomlinson PB. 1994. The botany of mangrove. Cambridge University Press. Cambridge.

Wilhm JL. 1975. Biological indicator of pollution in river ecological. Blackwell Scientific Publication. London.

Zurochman. 2003. Laju tangkap udang dan masalah jaring apong di pelawangan timur sebagai landasan manajemen perikanan Laguna Segara Anakan [Tesis]. Program Pascasarjana, Universitas Diponegoro. Semarang. 